\title{
ANALISIS KINERJA REKSA DANA SAHAM PADA PLATFORM PT. PHILLIP SEKURITAS INDONESIA
}

\author{
Lalu Pandrio Akbar \\ akbarvan89@gmail.com \\ Jurusan Akuntansi Fakultas Ekonomi dan Bisnis Universitas Mataram \\ Siti Atikah \\ siti.atikah@unram.ac.id \\ Jurusan Akuntansi Fakultas Ekonomi dan Bisnis Universitas Mataram \\ Indria Puspitasari Lenap \\ indrialenap@unram.ac.id \\ Jurusan Akuntansi Fakultas Ekonomi dan Bisnis Universitas Mataram
}

\begin{abstract}
ABSTRAK
Penelitian ini bertujuan untuk menganalisis kinerja reksa dana saham yang terdaftar pada platform PT. Phillip Sekuritas Indonesia. Penelitian ini menggunakan metode deskriptif kuantitatif untuk jangka waktu 1 tahun. Populasi dalam penelitian ini adalah 44 reksa dana saham yang terdaftar pada platform PT. Phillip Sekuritas Indonesia. Pengambilan sampel pada penelitian ini menggunakan kriteria yang sudah di tetapkan oleh peneliti yaitu 44 reksa dana saham. Variabel yang digunakan pada penelitian ini adalah Asset Under Management (AUM), Stock Selection, Fee Broker, dan Nilai Aktiva Bersih (NAB).

Penelitian ini menggunakan metode klasifikasi data dari masing-masing variabel. Hasil dari penelitian ini menunjukkan adanya besaran perhitungan dari masing-masing variabel terhadap kinerja reksa dana saham yang terdaftar di platform PT. Phillip Sekuritas Indonesia dengan keputusan memilih reksa dana saham tersebut. Selain itu penelitian ini menunjukkan besaran dari Asset Under Management (AUM), Stock Selection, Fee Broker, dan Nilai Aktiva Bersih (NAB) akan menjadi tolak ukur untuk investor untuk ber-investasi pada reksa dana saham yang terdaftar.

Kata Kunci : $\quad$ Reksa Dana Saham, Asset Under Management (AUM), Stock Selection, Fee Broker, dan Nilai Aktiva Bersih (NAB)
\end{abstract}

ABSTR $\boldsymbol{A C T}$

This study aims to analyze the performance of equity funds listed on the PT. Phillip Sekuritas Indonesia. This study used a quantitative descriptive method for a period of 1 year. The population in this study were 44 equity funds registered on the PT. Phillip Sekuritas Indonesia. Sampling in this study using criteria that have been set by the researcher, namely 44 equity funds. The variables used in this study are Asset Under Management (AUM), Stock Selection, Brokerage Fees, and Net Asset Value (NAV).

This study uses a data classification method for each variable. The results of this study indicate a calculation of each variable on the performance of equity funds listed on the PT. Phillip Sekuritas Indonesia with the decision to choose the equity mutual fund. In addition, this study shows that the amount of Asset Under Management (AUM), Stock Selection, Brokerage Fee, and Net Asset Value (NAV) will be a benchmark for investors to invest in listed equity funds.

Keywords: $\quad$ Equity Funds, Asset Under Management (AUM), Stock Selection, Brokerage Fees, and Net Asset Value (NAV).

\section{PENDAHULUAN}

Pada industri pasar modal Indonesia, regulator tertinggi terletak pada Otoritas Jasa Keuangan (OJK). Namun, ada tiga lembaga yang disebut sebagai Self Regulatory Organizations (SRO) yang punya kewenangan menerapkan aturan dari regulator.Sebagai salah satu pilar pendukung perekonomian nasional, Self Regulatory Organization (SRO) 
turut serta menyokong infrastruktur di bidang digital dan teknologi melalui perkembangan dan pemutakhiran sistem di sepanjang 2018. Masing-masing SRO telah menerapkan generasi terbaru sistem utama yaitu Bursa Efek Indonesia (BEI) dengan JATS Next-G, Kliring Penjaminan Efek Indonesia (KPEI) dengan Enhancement Architecture e-CLEARS (EAE) dan Kustodian Sentral Efek Indonesia (KSEI) dengan The Central Depository and Book Entry Settlement System Next Generation (C-BEST Next-G). Penerapan teknologi tersebut dapat menjadi nilai tambah yang positif dalam peranan ekonomi digital yang dijadikan prioritas Pemerintah Republik Indonesia (Bursa Efek Indonesia, 2019).

Dengan perkembangan teknologi yang semakin canggih di bidang pasar modal khususnya pada investasi jenis reksa dana, dimana saat ini nvestasi pada produk reksa dana banyak diminati oleh masyarakat. Agung dan Wirasedana (2014) mengungkap bahwa sudah banyak investor yang tertarik melakukan kegiatan investasinya dengan melakukan investasi tidak langsung. Dalam kegiatan investasi ini, saham atau surat-surat berharga dibeli melalui perusahaan investasi di mana perusahaan ini sebagai penyedia jasa keuangan dengan menjual saham yang dimiliki kepada publik atau calon investor dengan menggunakan dana yang diperoleh dari investor dan menginvestasikannya ke dalam portofolio investasi. Hal ini disebabkan karena investor yang bermodal kecil dapat memperoleh keuntungan dari portofolio tersebut. Apabila investor harus membentuk portofolio sendiri, maka investor tersebut harus membeli saham dalam jumlah yang tidak sedikit. Sehingga investor yang mempunyai dana sedikit namun ingin membentuk portofolio, maka investor dapat membeli portofolio saham pada perusahaan investasi ini.

Investasi yang dilakukan oleh masyarakat pada umumnya hanya terpaku pada mengalokasikan dananya kepada rill asset dan financial asset, investasi rill asset pada umumnya hanya diletakkan pada asset yang memiliki wujud atau bentuk seperti tanah, bangunan, emas, dan kekayaan rill lainnya, sedangkan pada financial asset lebih menekankan pada investasi pada asset keuangan berupa surat- surat berharga pasar uang maupun produk pasar modal lainnya. Dalam penelitian Hermawan dan Wiagustini (2016) menyebutkan bahwa perkembangan investasi yang semakin maju terutama di pasar modal atau Bursa Efek Indonesia sekarang ini menjadi salah satu alternatif yang menguntungkan, kesadaran akan pentingnya investasi memberikan banyak pilihan kepada masyarakat untuk instrument investasinya antara lain seperti saham, obligasi, reksa dana, waran, dan right.

Adapun jenis instrument investasi di pasar modal selain saham, obligasi, dan sukuk adalah reksa dana, di mana secara data menunjukkan bahwa jumlah investor reksa dana sejumlah 1.303.398 SID dengan presentase Year On Year (YOY) sejumlah 74,66\% dan Year To Date (YTD) sejumlah 41,72\% pada bulan September 2019. Melihat jumlah pertumbuhan minat investasi masyarakat khususnya pada produk Reksa dana (data Otoritas Jasa Keuangan), peneliti bertujuan untuk meneliti sejauh mana kinerja Reksa dana saham yang terdaftar di salah satu perusahaan sekuritas di indonesia jika dilihat dari total Asset Under Management (AUM), Stock Selection, Fee Broker, dan Nilai Aktiva Bersih (NAB). Sejalan dengan itu reksa dana menurut Undang-undang Pasar Modal No.8 Tahun 1995 Pasal 1 Ayat 27 reksa dana didefinisikan sebagai wadah yang dipergunakan untuk menghimpun dana dari masyarakat pemodal untuk selanjutnya diinvestasikan dalam portofolio efek oleh manajer investasi. 


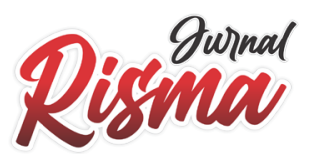

Vol. 1 No. 4 Desember 2021

Hermawan dan Wiagustini (2016) menyebutkan di dalam penelitiannya bahwa reksa dana merupakan salah satu alternatif menghimpun dana dari masyarakat, investasi reksa dana merupakan investasi yang disebarkan pada sekian alat investasi yang diperdagangkan di pasar modal dan pasar uang. Reksa dana awal mula berkembang di negara Belgia pada tahun 1822 yang berbentuk reksa dana tertutup. Pada tahun 1860, reksa dana mulai menyebar ke inggris dan Skotlandia dalam bentuk Unit Investment Trust dan pada tahun 1920 mulai dikenal di Amerika Serikat dengan nama Mutual Fund, sedangkan di Indonesia reksa dana mulai diperdagangkan di Indonesia sejak tahun 1995 dengan keluarkannya Undang Undang No.8 tahun 1995 tentang pasar modal.

Mutual Fund, Unit Trust dan reksa dana pada prinsipnya ketiga istilah tersebut memiliki arti yang sama, hanya sumbernya berlainan, misalnya Mutual Fund berasal dari istilah Amerika Serikat, Unit Trust berasal dari Inggris, sedangkan Reksa dana berasal dari Indonesia. Demikian pula dengan kegiatannya ketiga nama tersebut bisa dikatakan hampir serupa bahkan, bahkan perusahaan itu disebut perusahaan investasi (investment company) atau dana bersama (mutual fund) (Ahmad , 2004 : 2015).

Adapun kegiatan dari usaha dari perusahaan investasi ini adalah dengan cara mengumpulkan dana dari berbagai lembaga investor atau perorangan. Kemudian perusahaan itu menginvestasikannya ke dalam bebagai media investasi seperti pasar modal (capital market), pasar uang (money market), atau mata uang asing (currency), dan Properti. Penelitian terdahulu yang dilakukan oleh Wibowo (2017) menyatakan terdapat 1.089 reksa dana aktif yang dikelola oleh 85 manajer investasi di Indonesia. Diantara berbagai reksa dana ini, jenis reksa dana saham menjadi salah satu reksa dana yang paling banyak diminati investor karena dapat menawarkan imbal hasil yang lebih tinggi dibanding dengan reksa dana jenis lain. Namun, seiring dengan kemampuan untuk menghasilkan imbal yang tinggi, reksa dana saham juga diiringi dengan risiko yang tinggi pula, sehingga penilaian imbal hasil terhadap risiko reksa dana sangat penting untuk dilakukan (risk adjusted return).

Berdasarkan data (Bareksa) sepanjang bulan Juni 2020 IHSG menguat 1,19 persen seiring meredanya ketegangan pasar akibat pandemi Covid-19. Catatan kinerja IHSG turut mendorong kinerja reksadana berbasis saham, yakni reksadana saham dan campuran. Sepanjang Juni 2020, indeks reksadana saham dan indeks reksadana campuran membukukan return tertinggi dibandingkan indeks reksadana lainnya, dengan return masing-masing 1,69 persen sebulan. Kinerja positif juga dibukukan indeks reksadana campuran syariah dengan return 1,13 persen, indeks reksadana pendapatan tetap 0,63 persen dan indeks reksadana pendapatan tetap syariah 0,47 persen.

Namun kinerja negatif sepanjang bulan tersebut dicatatkan indeks reksadana saham syariah -0,13 persen, indeks reksadana pasar uang -0,09 persen dan indeks reksadana pasar uang syariah $-0,04$ persen. Meskipun reksadana saham masih mencatatkan kinerja return tertinggi, namun nilai imbal hasilnya sedikit turun dibandingkan Mei 2020. Sepanjang Mei 2020, indeks reksadana saham membukukan return 2,77 persen (PT. Bareksa Portal Investasi, 2020). Dalam penelitian yang dilakukan oleh Rafika dan Laila (2017) dikutip dari (Tandelilin, 2010:516) dalam mengelola suatu portofolio manajer investasi dapat menggunakan strategi pasif dan strategi aktif. Strategi pasif merupakan strategi dimana manajer investasi tidak memerlukan analisis saham selama periode saham itu dipegang. Sedangkan strategi aktif merupakan strategi dimana manajer investasi akan melakukan tindakan-tindakan aktif dan proaktif terhadap keputusan investasi dengan secara aktif 
mencari informasi dan melakukan peramalan-peramalan terhadap perilaku pasar ataupun nilai tukar berdasarkan informasi yang diperolehnya sedangkan Strategi aktif ini dilakukan dengan menggunakan kemampuan yang dimiliki manajer investasi yaitu kemampuan memilih sekuritas (stock selection) dan kemampuan pengukuran waktu pasar (market timing).

Menurut Paramitha dan Purnawati (2017: 4019-4047), masyarakat yang selanjutnya disebut sebagai investor dalam melakuka kegiatan investasinya selalu melihat dua parameter, yaitu risiko dan return investor cenderung untuk memilih investasi dengan return yang sebanding dengan tingkat risikonya. Didalam teori portofolio disebutkan, portofolio yang efisien adalah portofolio dengan risiko tertentu yang menghasilkan return yang optimal. Pada dasarnya return yang besar dari suatu investasi disertai dengan risiko yang besar pula. Oleh karena itu, setiap investor perlu memperhatikan aspek risiko dan return setiap investasi yang akan dilakukannya. Untuk mengurangi risiko suatu investasi, investor dapat melakukan diversifikasi pada beberapa instrumen investasi (Barus dan Mahfud, 2013).

Penelitian yang dilakukan oleh Agung dan Wirasedana (2014) Seorang investor memerlukan pengalaman serta pengetahuan yang baik. Akan tetapi, bagi investor baru yang tidak mempunyai pengalaman serta pengetahuan tidak akan bisa membentuk suatu portofolio yang memberikan keuntungan optimal, tetapi ia dapat memilih alternative yaitu membeli portofolio saham yang ditawarkan oleh perusahaan investasi ini, sehingga muncul berbagai pandangan masyarakat umum, terutama bagi investor baru, di mana untuk berinvestasi di pasar modal memerlukan dana yang besar dan pengetahuan serta pengalaman yang cukup sehingga dapat membentuk portofolio saham agar memberikan return yang maksimal. Berdasarkan hal tersebut, terbentuklah lembaga investasi baru yaitu reksa dana.

Dari 93 Manajer Investasi yang ada di Indonesia yang menerbitkan produk reksa dana fokus penelitian ini pada reksa dana saham yang terdaftar pada PT. Phillip Sekuritas Indonesia, di mana PT. Phillip Sekuritas Indonesia merupakan salah satu perusahaan broker atau pialang yang menyediakan platform untuk transaksi jual beli produk - produk pasar modal Indonesia seperti saham dan reksa dana. PT. Phillip Sekuritas Indonesia menyediakan sistem transaksi online bernama Phillip's Online Electronic Mart System (POEMS), sampel jumlah reksa dana yang menjadi penelitian ini adalah 44 reksa dana saham yang terdaftar di platform PT. Phillip Sekuritas Indonesia Tahun 2019.

Dalam Penelitian yang dilakukan oleh Oswari dan Kowanda (2007), Barus dan Mahfud (2013), Agung dan Wirasedana (2014), Alexandri (2015), Putri dan Puspita, Dwiperkasa dan Dharmastuti (2016), Hermawan dan Wiagustini (2016), Pangestuti, Wahyudi, Robiyanto (2017), Worokinasih, (2018), lebih menekankan pada mengukur tingkat kinerja suatu reksadana dengan alat ukur seperti metode sharpe, treynor, dan Jensen dengan pendekatan analisa data menggunakan sistem pengolahan data SPSS.

Dari beberapa penelitian yang sudah dilakukan oleh peneliti sebelumnya adapun alasan peneliti ingin meneliti lebih lanjut terkait dengan topik reksa dana saham adalah karena adanya variabel baru yang dimasukkan ke dalam penelitian ini yaitu fee Broker yang mana pada penelitian sebelumnya tidak terdapat variabel yang memabahas tentang fee Broker. Maka dari itu, peneliti perlu mengadakan penelitian lebih lanjut mengenai“"Analisis Reksa Dana Saham Pada Platform PT. Phillip Sekuritas Indonesia", PT Phillip Sekuritas Indonesia merupakan salah satu prusahaan sekuritas yang ada di 


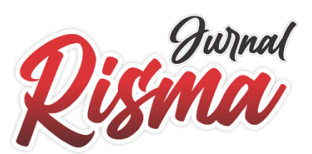

Vol. 1 No. 4 Desember 2021

Indonesia yang memfasilitasi pembelian efek berupa saham, reksa dana, exchange trade fund (ETF), obligasi, dan produk pasar modal lainnya.

Penelitian ini mereplikasi dari penelitian Agung dan Wirasedana (2014), dan Putri (2014) di dalam penelitian sebelumnya menganalisis kinerja reksa dana saham dengan kebijakan alokasi assetnya dan mengukur tingkat stock selection, market timing ability terhadap kinerja reksa saham di Indonesia, sehingga dari refrensi penelitian sebelumnya peneliti ingin mengembangkan lebih dalam lagi dengan menambah 3 variabel yaitu, Asset Under Management (AUM), Fee Broker, Nilai Aktiva Bersih (NAB).

Berdasarkan uraian latar belakang diatas peneliti menguraikan rumusan masalah sebagai berikut: (1). Apakah reksa dana saham di Platform PT. Phillip Sekuritas Indonesia memiliki kinerja yang baik jika dilihat dari tingkat pertumbuhan pengelolaan dana manajer investasi atau Asset Under Management (AUM) (2). Apakah reksa dana saham di Platform PT. Phillip Sekuritas Indonesia memiliki kinerja yang baik jika dilihat dari kebijakan alokasi investasi atau Stock Selection. (3). Apakah reksa dana saham di Platform PT. Phillip Sekuritas Indonesia memiliki kinerja yang baik jika dilihati dari tingkat fee Broker. (4). Apakah reksa dana saham di Platform PT. Phillip Sekuritas Indonesia memiliki kinerja yang baik jika dilihat dari tingkat Nilai Aktiva Bersih (NAB).

\section{TINJAUAN LITERATUR}

Tujuan pembentukan portofolio adalah mengurangi risiko dengan penganekaragaman kepemilikan efek. Parameter penilaian yang digunakan dalam analisis portofolio adalah ekspektasi return dan standar deviasi yang dikombinasikan dalam beberapa instrumen investasi. Investor yang rasional akan menginvestasikan dananya dengan memilih instumen investasi yang efisien, yang memberikan return maksimal dengan risiko tertentu, atau return tertentu dengan risiko minimal. Investor perlu melakukan strategi diversifikasi atas investasinya dengan membentuk portofolio yang terdiri atas beberapa instrumen investasi yang dinilai efisien untuk memperkecil atau meminimalkan risiko. Menurut (Sharpe, 1995), portofolio dikategorikan efisien apabila memiliki tingkat risiko yang sama, mampu memberikan tingkat keuntungan yang lebih tinggi, atau mampu menghasilkan tingkat keuntungan yang sama, tetapi dengan risiko yang lebih rendah.

Dasar pemilihan portofolio pertama kali dicetuskan oleh Harry M Markowitz pada tahun 1952 yang disebut dengan teori portofolio Markowitz. Teori portofolio Markowitz didasarkan atas pendekatan mean (rata-rata) dan variance (varian), dimana mean merupakan pengukuran tingkat return dan varian merupakan pengukuran tingkat risiko. Teori portofolio Markowitz ini disebut juga sebagai mean-variance model, yang menekankan pada usaha memaksimalkan ekspektasi return (mean) dan meminimumkan ketidakpastian atau resiko untuk memilih dan menyusun portofolio optimal.

Portofolio investasi terdiri dari kumpulan berbagai macam aset mulai dari saham, obligasi, properti ataupun reksadana. Investor menyusun portofolio dengan harapan untuk mencapai tujuan investasinya. Komposisi dari portofolio tergantung dari beberapa faktor namun yang paling penting adalah batas tolerenasi dari investor itu sendiri, jangka waktu untuk memegang aset investasi dan modal investasi. Portofolio investasi selalu dibandingkan dengan pasar, khususnya tingkat pengembalian atau return. Risiko dari portofolio diukur melalui varians return portofolio terhadap return pasar. Pada suatu 
portofolio, diversifikasi sangat penting untuk mengurangi risiko-risiko di saat aset yang dipegang mengalami kerugian.

Berdasarkan Undang-Undang Nomor 8 tahun 1995 tentang Pasar Modal (UU No. 8/1995), Reksa dana adalah wadah yang dipergunakan untuk menghimpun dana dari masyarakat pemodal untuk selanjutnya diinvestasikan dalam portofolio efek oleh Manajer Investasi. Manajer Investasi, sebagaimana didefinisikan oleh undang - undang tersebut, adalah pihak yang kegiatan usahanya mengelola Portofolio Efek untuk para nasabah atau mengelola portofolio investasi kolektif untuk sekelompok nasabah, termasuk dalam hal ini adalah mengelola Reksa dana.

Berdasarkan bentuk hukumnya, sebagaimana diatur pada UU No. 8/1995 pada pasal 18 ayat (1), Reksa dana dapat diklasifikasikan dalam 2 bentuk yaitu, Reksa dana Perseroan dan Reksa dana Kontrak Investasi Kolektif. Kedua bentuk Reksa dana ini sama-sama menghimpun dan menginvestasikan dananya pada berbagai instrumen investasi baik yang diperdagangkan di pasar modal maupun di pasar uang.

Reksa dana merupakan salah satu alternatif investasi bagi investor kecil atau investor yang tidak banyak memiliki waktu dan kemampuan untuk menghitung risiko atas investasi yang dilakukan. Kegiatan investasi pada reksadana adalah penghimpunan dana dari investor dan dikelola oleh manajer investasi dengan membentuk portfolio. Reksa dana walaupun tergolong baru di Indonesia, yaitu diperkenalkan pada tahun 1995 namun dapat berkembang dengan pesat, Investasi dalam reksa dana menunjukkan hasil yang bervariasi sehingga tidak ada jaminan bahwa berinvestasi pada reksa dana akan menghasilkan return yang lebih tinggi dibandingkan berinvestasi secara langsung, demikian juga sebaliknya. Namun umumnya investor dihadapkan pada kendala-kendala seperti kecukupan modal dan ketersediaan waktu dan pengetahuan dalam pengelolaan portofolio, sehingga investasi pada reksa dana merupakan alternatif pilihan. Keinginan investor untuk memperoleh pendapatan yang lebih baik antara lain juga memerlukan informasi yang diharapkan bisa digunakan untuk meramalkan kinerja pada masa mendatang (Marna, 2016)

Didalam modul yang diterbitkan oleh PT. Bursa Efek Indonesia (2017), pada dasarnya setiap individu yang berinvestasi selalu ingin mendapatkan keuntungan dalam investasinya. Keuntungan tersebut akan terasa penting bagi investor yang lebih mengutamakan strategi konservatif atas pengelolaan dananya. Dibandingkan dengan instrumen investasi lain berikut manfaat berinvestasi pada Reksa dana: (1). Dikelola secara profesional oleh Manajer Investasi. (2). Biaya rendah. (3). Diversifikasi Investasi. (4). Transparan Informasi. (5). Tingginya Tingkat Likuiditas. Menurut definisinya, AUM atau dana kelolaan pada reksadana mengacu pada total nilai dari investasi yang dikelola oleh manajer investasi. Biasanya, manajer investasi yang mengelola aset-aset ini mengambil keputusan investasi atas nama investor. Asset Under Management (AUM) adalah indikator ukuran keberhasilan sebuah reksadana.

Istilah AUM juga biasa disebut dengan Nilai Aktiva Bersih (NAB) suatu produk reksadana. AUM juga bisa merujuk pada total dana yang dikelola oleh manajer investasi. Kita bisa saja menyebut total semua uang kelolaan sebuah produk reksadana dengan AUM. Akan tetapi, kita tidak bisa menyebut semua dana yang dikelola oleh manajer investasi sebagai NAB. 


\section{Rerangka Konseptual}

Sesuai dengan rumusan masalah, penelitian ini bertujuan untuk memberikan suatu pandangan terhadap kinerja Manajer Investasi yang ada di PT. Phillip Sekuritas Indonesia yang di proksikan dengan Asset Under Management (AUM), alokasi investasi atau stock selection, Fee Broker, dan Nilai Aktiva Bersih dari per unit. Rerangka konseptual dari penelitian ini dapat digambarkan sebagai berikut:

Gambar 1.1. Rerangka Konseptual

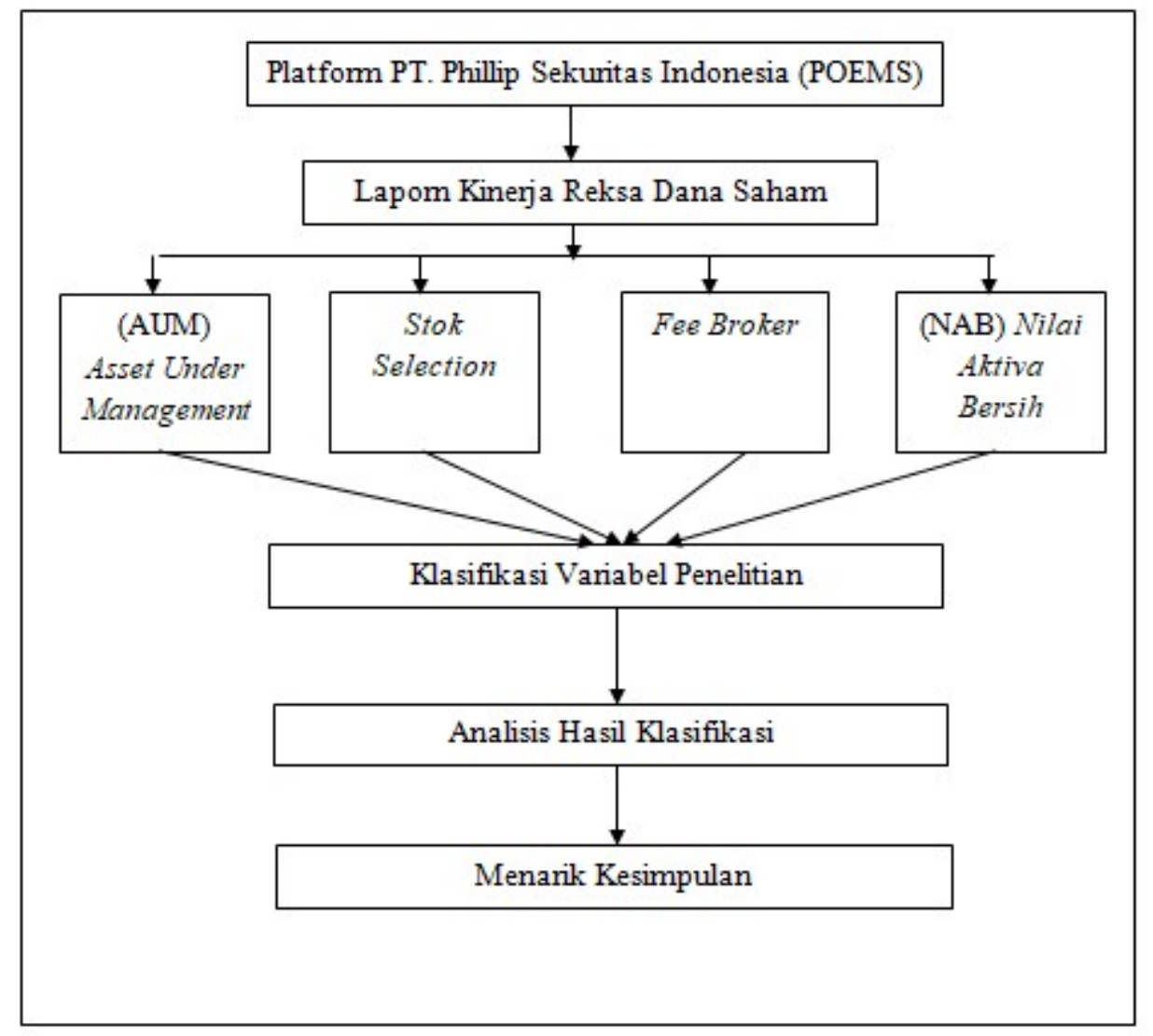

\section{METODE PENELITIAN}

Jenis penelitian ini adalah penelitian deskriptif kuantitatif. Penelitian deskriptif dengan pendekatan kuantitatif yaitu mengolah data untuk memperoleh data berbentuk angka dan menjelaskan serta menggambarkan fenomena - fenomena yang akan di teliti (Mulyana, 2016). Penelitian deskriptif kuantitatif dalam penelitian ini peneliti ingin mencari hubungan antara variabel yang dipengaruhi yaitu Kinerja reksa dana saham dan variabel yang mempengaruhi yaitu Asset Under Management (AUM), Stock Selection, Fee Broker, dan Nilai Aktiva Bersih (NAB). Selain itu, penelitian ini berfokus pada penelitian yang sifatnya terapan hanya sebagai acuan untuk berinvestasi pada reksa dana saham

Penelitian ini dilakukan pada reksa dana saham yang terdaftar di dalam Platform PT. Phillip Sekuritas Indonesia, dengan sumber data berasal dari Phillip Online Electronic Market System (POEMS). Teknik pengambilan sampel yang digunakan adalah purposive sampling. Teknik purposive sampling adalah teknik penentuan sampel dengan pertimbangan 
tertentu. Kriteria penentuan sampel pada penelitian ini yaitu: (1). Reksa dana saham yang terdaftar di platform PT. Phillip Sekuritas Indonesia dan menerbitkan laporan keuangan Tahun 2019. (2). Reksa dana saham yang tidak memiliki informasi terkait dengan fee broker dalam laporan keuangan. (3). Reksa dana saham yang tidak memiliki data lengkap terkait Nilai Aktiva Bersih (NAB) produk Reksa dana Saham yang dikeluarkan.

Tabel 2.1 Tabel Kriteria Pengambilan Sampel

\begin{tabular}{|l|l|}
\hline Keterangan & Jumlah Reksadana \\
\hline $\begin{array}{l}\text { Reksa dana saham yang terdaftar di platform PT. Phillip } \\
\text { Sekuritas Indonesia dan menerbitkan laporan keuangan } \\
\text { Tahun } 2019\end{array}$ & 44 \\
\hline $\begin{array}{l}\text { Reksa dana saham yang tidak memiliki informasi terkait } \\
\text { dengan fee broker dalam laporan keuangan }\end{array}$ & $(0)$ \\
\hline $\begin{array}{l}\text { Reksa dana saham yang tidak memiliki data lengkap terkait } \\
\text { dikeluarkan Aktiva Bersih produk Reksa dana Saham yang }\end{array}$ & $(0)$ \\
\hline Jumlah akhir sampel & 44 \\
\hline Total observasi penelitian & 44 \\
\hline
\end{tabular}

Sumber : website resmi PT. Phillip Sekuritas Indonesia).

Metode pengumpulan data yang digunakan dalam penelitian ini adalah studi dokumentasi, yaitu pengumpulan data melalui dokumen tertulis berupa laporan keuangan tahunan reksadana yang dikeluarkan oleh manajer investasi untuk mendapatkan data proporsi berupa Asset Under Management (AUM), Stock Selection, Fee Broker, dan Nilai Aktiva Bersih (NAB). Data tersebut diperoleh melalui literatur, buku dan situs dari internet Phillip Online Electronic Market System (POEMS).

\section{PEMBAHASAN}

Berikut Hasil Klasifikasi Asset Under Management (AUM)

\section{Tabel 2.2}

Klasifikasi Asset Under Management (AUM)

\begin{tabular}{|l|l|l|l|}
\hline No & Nama Reksa Dana & Total AUM 2019 & Fee Broker \\
\hline 1 & Simas Syariah Unggulan & Rp 33,558,000,000,000.00 & $2.50 \%$ \\
\hline 2 & Simas Saham Unggulan & Rp 24,134,000,000,000.00 & $2.50 \%$ \\
\hline 3 & $\begin{array}{l}\text { Principal Islamic Equity } \\
\text { Growth Syariah }\end{array}$ & Rp 13,307,600,000,000.00 & $5.00 \%$ \\
\hline
\end{tabular}




\begin{tabular}{|c|c|c|c|}
\hline No & Nama Reksa Dana & Total AUM 2019 & Fee Broker \\
\hline 4 & PNM Saham Agresif & $\operatorname{Rp} 9,029,000,000,000.00$ & $3.00 \%$ \\
\hline 5 & Batavia Dana Saham & $\operatorname{Rp~5,644,139,806,195.29~}$ & $3.00 \%$ \\
\hline 6 & $\begin{array}{l}\text { Reksa Dana Eastspring } \\
\text { Investments }\end{array}$ & $\operatorname{Rp} 3,067,000,000,000.00$ & $2.50 \%$ \\
\hline 7 & $\begin{array}{l}\text { BNI-AM Dana Saham } \\
\text { Inspiring }\end{array}$ & $\operatorname{Rp~1,473,117,094,762.22}$ & $2.99 \%$ \\
\hline 8 & BNP Paribas Pesona & $\operatorname{Rp} 1,066,000,000,000.00$ & $2.50 \%$ \\
\hline 9 & BNP Paribas Infrastruktur & $\operatorname{Rp~1,003,000,000,000.00}$ & $2.50 \%$ \\
\hline 10 & $\begin{array}{l}\text { First State Indo Equity Dividend } \\
\text { Yield Fund }\end{array}$ & $\operatorname{Rp} 969,161,900,217.00$ & $3.00 \%$ \\
\hline
\end{tabular}

Dari data yang tertera di atas peneliti dapat menarik penjelasakan bahwa semakin tinggi tingkat Asset Under Management (AUM) yang dimiliki oleh suatu reksa dana tentunya akan menjadi tolak ukur terhadap kepercayaan investor untuk menanamkan modalnya pada reksa dana itu sendiri. Sehingga dari besaran total klasifikasi Asset Under Management (AUM) yang 10 tertinggi berdasarkan data diatas memiliki kinerja yang cukup baik. Secara sederhana Asset Under Management (AUM) itu sendiri menggambarkan tingkat kepercayaan investor untuk penempatan dan yang aka dikelola oleh reksa dana itu sendiri dengan harapan memiliki imbal hasil yang besar tapi dengan biaya yang sekecil- kecilnya sehingga penelitian memberikan penjelasan bahwa besaran Asset Under Management (AUM) yang dikelola di dalam reksa dana saham tersebut dapat di jadikan sebagai tolak ukur untuk melihat kinerja reksa dana saham di platform PT. Phillip Sekuritas Indonesia.

Penelitian ini sesuai dengan teori yang tercantum dalam penelitian (Pratomo dan Nugraha, 2009). yang menyatakan bahwa makin besar total net asset atau Asset Under Management (AUM) yang dimiliki oleh reksa dana, semestinya akan menghasilkan fleksibilitas yang tinggi terhadap suatu reksa dana tersebut dalam mengupayakan pelayanan terbaik kepada nasabahnya. Sehingga, semakin besar total net asset atau Asset Under Management (AUM) semestinya berdampak pada fleksibilitas pelayanan reksa dana tersebut dan memberikan keuntungan berupa economies of scale atau pengurangan beban biaya untuk nasabah Hasil penelitian ini sejalan dengan (Pratiwi, 2010) yang menunjukkan hasil pengujian menunjukkan secara parsial bahwa ukuran reksa dana berkaitan dengan kinerja reksa dana itu sendiri. Sehingga dapat di tarik penjelasan bahwa semakin besar total Asset Under Management (AUM) yang di miliki oleh suatu reksa dana saham akan semakin memiliki kinerja yang baik. 


\section{Hasil Klasifikasi \\ Stock Selection}

Stock selection atau klasifikasi investasi merupakan strategi dengan tindakan secara aktif melakukan analisis dan memilih saham-saham dengan kategori yang baik atau yang disebut saham superior. Saham superior yang dimaksud disini yaitu saham-saham yang memberikan hubungan tingkat return dan risiko yang terbaik dibandingkan alternative yang lainnya. Tindakan tersebut dilakukan bertujuan untuk dapat meningkatkan return yang diharapkan investor.

Manajer investasi mempunyai kewajiban untuk melaksanakan investasi bagi kepentingan investor sesuai dengan kontrak yang ada. Sedangkan, untuk bank kustodian berkewajiban untuk menyimpan, menjaga dan mengawasi dana investor dan menghitung Nilai Aktiva Bersih (NAB) per unit penyertaan dalam reksa dana saham. Sehingga atas pemberian jasa dalam pengelolahan investasi serta penyimpanan dana kolektif tersebut, manajer investasi dan bank kustodian berhak memperoleh imbal jasa yang dihitung atas presentase yang telah disepakati dari nilai NAB reksa dana saham pada saat kontrak awal ditandatangani. Dan apabila dalam hal kontrak di awal manajer investasi atau bank kustodian tidak melaksanakan amanah dari investor sesuai dengan kewenangan yang diberikan atau manajer investasi dan bank kustodian dianggap lalai, maka manajer investasi dana atau bank kustodian bertanggung jawab atas resiko yang ditimbulkannya.

Berdasarkan hasil pengumpulan data yang terlampir pada lampiran 3, bahwa kebijakan alokasi asset yang dilakukan oleh manajer investasi sebagian besar tetap berpatokan pada kebijakan alokasi asset yang sudah ditetapkan dalam masing-masing fund factsheet atau masing-masing reksa dana yaitu untu jenis reksa dana saham komponen kebijakan alokasi assetnya 80\%-100\% masuk ke dalam instrument saham dan 0\%-20\% bisa dimasukkan kedalam instrument investasi yang lainnya, hal ini di buktikan jika instrument investasi dimasukkan $80 \%-100 \%$ ke dalam instrument inevstasi portofolio saham akan menghasilkan return yang lebih tinggi dilihat dari Bachmark atausuku bungan acuan reksa dana tersebut, hal ini di buktikan pada tabel kebijakan alokasi asset berikut dengan sampel 10 Reksa dana dengan tingkat kelolaan dana yang tinggi.

Tabel 2.3

Tabel Stock Selection

\begin{tabular}{|l|l|l|l|l|}
\hline No & \multicolumn{1}{|c|}{ Nama Reksa dana } & \multicolumn{1}{|c|}{$\begin{array}{c}\text { Return Sejak } \\
\text { Peluncuran }\end{array}$} & \multicolumn{1}{|c|}{ Saham } & Lain-lain \\
\hline 1 & Simas Syariah Unggulan & $11,59 \%$ & $99,61 \%$ & $0,38 \%$ \\
\hline 2 & Simas Saham Unggulan & $88,59 \%$ & $95,31 \%$ & $4,69 \%$ \\
\hline 3 & $\begin{array}{l}\text { Principal Islamic Equity Growth } \\
\text { Syariah }\end{array}$ & $45,94 \%$ & $89,81 \%$ & $10,39 \%$ \\
\hline 4 & PNM Saham Agresif & $-1902.00 \%$ & $80,74 \%$ & $19,92 \%$ \\
\hline 5 & Batavia Dana Saham & $6263.53 \%$ & $83,43 \%$ & $16,57 \%$ \\
\hline
\end{tabular}




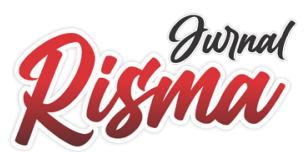

Vol. 1 No. 4 Desember 2021

\begin{tabular}{|l|l|l|l|l|}
\hline No & \multicolumn{1}{|c|}{ Nama Reksa dana } & $\begin{array}{c}\text { Return Sejak } \\
\text { Peluncuran }\end{array}$ & \multicolumn{1}{|c|}{ Saham } & Lain-lain \\
\hline 6 & $\begin{array}{l}\text { Reksa dana Eastspring } \\
\text { Investments }\end{array}$ & $27,62 \%$ & $93,05 \%$ & $6,95 \%$ \\
\hline 7 & BNI-AM Dana Saham Inspiring & $3,94 \%$ & $92,00 \%$ & $8,00 \%$ \\
\hline 8 & BNP Paribas Pesona & $16,18 \%$ & $90,44 \%$ & $9,56 \%$ \\
\hline 9 & BNP Paribas Infrastruktur & $9,31 \%$ & $91,46 \%$ & $8,54 \%$ \\
\hline 10 & $\begin{array}{l}\text { First State IndoEquity Dividend } \\
\text { Yield Fund }\end{array}$ & $11,79 \%$ & $86,61 \%$ & $13,39 \%$ \\
\hline
\end{tabular}

Hasil penelitian ini menunjukkan bahwa dalam melakukan investasi pada Reksadana Saham seorang investor harus mempertimbangkan beberapa aspek yang salah satunya yaitu mengenai komponen isi dari reksa dana saham tersebut. Begitu pula dengan pengelola reksa dana saham yaitu, manajer investasi dituntut untuk memiliki kemampuan memilih komposisi saham mana saja yang mampu memberikan keuntungan yang paling maksimal, serta mampu melakukan peramalan waktu yang tepat atas instrument investasi tersebut sehingga return reksadana yang dihasilkan mampu memberikan hasil yang maksimal, sehingga dari penjelasan di atas kinerja reksa dana saham jika dilihat dengan menggunakan stock selection semakin tepat penempatan komposisi investasi pada reksa dana saham maka reksa dana saham memiliki tingkat kinerja yang maksimal, sehingga penelitia dapat menarik suatu penjelasan bahwa besaran alokasi asset dalam komposisi reksa dana saham tersebut dapat dijadikan tolak ukut dari kinerja dari reksa dana saham di platform PT. Phillip Sekuritas Indonesia.

Penelitian ini sejalan dengan teori portofolio yang menjelaskan mengurangi risiko dengan penganekaragaman kepemilikan efek. Parameter penilaian yang digunakan dalam analisis portofolio adalah ekspektasi return dan standar deviasi yang dikombinasikan dalam beberapa instrumen investasi. Selain itu penelitian yang dilakukan oleh Nurcahya (2010) menyebutkan bahwa tingkat risiko reksadana berrgantung pada kebijakan alokasi aset yang artinya bagaimana manajer investasi mengalokasikan dananya pada kelas-kelas aset yang tersedia dan seberapa besar porsi pendistribusian dananya sehingga hal tersebut juga akan mempengaruhi kinerja ataupun return dari reksadana.

Dari data yang diperoleh peneliti dan juga melihat pada penelitian sebelumnya peneliti dapat menarik penjelasan bahwa secara pendangan dengan hanya melihat pada besaran komposisi isi dari reksa dana saham itu dan mempunyai komposisi yang bagus maka kinerja dari reksa dana saham itu sejalan dengan komposisi dari isi reksa dana itu sendiri. Sehingga dari data tersebut bahwa untuk penempatan komposisi saham pada reksa dana itu antaran 90\% ke atas memiliki kinerja yang baik.

Ada satu komposisi saham yaitu PNM Saham Agresif yang mana return sejak peluncuran mengalami penurunan dengan alokasi asset $80 \%$ ke atas hal ini dikarenakan pada komponen isi reksa dana ini sebagian besar dimasukkan ke saham-saham LQ-45 dengan 
komposisi BBRI, TLKM, BMRI, BBCA, dan ASII. Sehingga dari data fund fachsheet dari reksa dana ini sendiri memiliki acuan Bachmark Indeks Harga Saham Gabungan (IHSG) dan umur dari reksa dana ini sendri baru 1 tahun dimana pada saat bulan juni 2019 komponen isi nya mengalami penurunan yang cukup dalam diikuti dengan Benchmark-nya yang sejalan dengan penurunan komponen isinya.

\section{Hasil Klasifikasi Fee Broker}

Dari data yang didapatkan berupa klasifikasi fee broker yang terdapat di lampiran 4 dimana ada terdapat 10 reksadana dengan tingkat fee broker yang cukup tinggi di antara lain sebagai berikut :

Tabel 2.4

Tabel Klasifikasi Fee Broker

\begin{tabular}{|l|l|r|r|}
\hline No & \multicolumn{1}{|c|}{ Nama Reksa Dana } & Total AUM 2019 & $\begin{array}{c}\text { Fee Broker } \\
\mathbf{2 0 1 9}\end{array}$ \\
\hline 1 & Simas Syariah Unggulan & Rp 33,558,000,000,000.00 & $2.50 \%$ \\
\hline 3 & Simas Saham Unggulan & Rp 24,134,000,000,000.00 & $3.50 \%$ \\
\hline 4 & $\begin{array}{l}\text { Principal Islamic Equity } \\
\text { Growth Syariah }\end{array}$ & Rp 13,307,600,000,000.00 & $5.00 \%$ \\
\hline 5 & Batavia Dana Saham & Rp 9,029,000,000,000.00 & $3.00 \%$ \\
\hline 6 & $\begin{array}{l}\text { Reksa Dana Eastspring } \\
\text { Investments }\end{array}$ & Rp 3,067,000,000,000.00 & $3.00 \%$ \\
\hline 7 & $\begin{array}{l}\text { BNI-AM Dana Saham } \\
\text { Inspiring }\end{array}$ & $R p 4,139,806,195.29$ & $2.50 \%$ \\
\hline 8 & BNP Paribas Pesona & Rp 1,066,000,000,000.00 & $2.99 \%$ \\
\hline 9 & BNP Paribas Infrastruktur & Rp 969,161,900,217.00 & $3.00 \%$ \\
\hline 10 & First State IndoEquity \\
Dividend Yield Fund & & $2.50 \%$ \\
\hline
\end{tabular}

Sehingga jika ditarik penjelasan, dikarenakan untuk penelitian sebelumnya terkait dengan fee broker belum ada yang meneliti, penulis bisa menarik suatu penjelasan bahwa semakin tinggi tingkat fee yang dikeluarkan oleh manajer investasi terhadap produknya maka semakin kecil minat investasi pada produk reksa dana yang diterbitkan, berdasarkan hal tersebut dapat di tarik penjelasan bahwa besaran fee yang dikeluarkan oleh investor terhadap reksa dana saham tersebut dapat dijadikan sebagai tolak ukur minat investasi pada reksa dana saham di platform PT. Phillip Sekuritas Indonesia.

Berdasarkan modul Soemarto Lisa (2019) menyebutkan pada saat pembelian reksa dana ada biaya pembelian dan pada saat penjualan ada biaya penjualan. Terkadang biaya pembelian untuk setiap reksa dana berbeda-beda terkadang biaya tersebut juga berbeda di setiap agen penjualan, sedangkan biaya penjualan selain berbeda untuk setiap reksa dana 


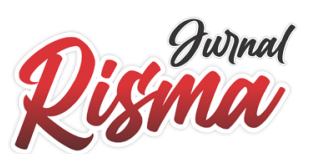

Vol. 1 No. 4 Desember 2021

juga ditentukan oleh berapa lama investor memiliki reksa dana tersebut, semakin lama investor memiliki reksa dana tersebut semakin kecil biaya yang akan dikeluarkan, bahkan tidak ada biaya sama sekali.

Sejalan dengan data di atas reksa dana saham yang memiliki kinerja yang baik dilihat dengan penilaian besar Asset Under Management (AUM) yang dihasilkan tinggi dan memiliki tingkat fee yang rendah, sehingga peneliti dapat memberikan suatu argumentasi bahwa jika melihat kinerja manajer investasi dari besaran fee yang dikeluarkan tentunya jika nilai fee yang dikeluarkan sedikit semakin banyak investor akan meletakkan dananya pada produk reksa dana saham suatu manajer investasi, sehingga kinerja manajer investasi sendiri dari data di atas dapat dilihat semakin kecil fee yang dikeluarkan oleh investor dan keuntungan yang diberikan maksimal manajer investasi memiliki kinerja yang cukup baik.

Untuk melihat perbandingannya dalam penelitian ini dapat di lihat pada tabel di bawah ini dimana dengan tingkat fee yang tinggi tentunya akan berpengaruh terhadap total dana yang akan dikelola oleh reksa dana itu sendiri. Sehingga dari data di atas penilit memberikan penjelasan bahwa kinerja reksa dana saham itu jika di lihat darifee broker, atau biaya yang dikeluarkan tentunya akan memiliki kinerja yang baik apabila total dari biaya yang dikeluarkan kecil.

\section{Hasil Klasifikasi Nilai Aktiva Bersih (NAB)}

Nilai investasi Reksa Dana, sesuai dengan peraturan yang berlaku, dihitung setiap hari sesuai dengan periode/hari perdagangan bursa (hari bursa). Total nilai investasi di dalam produk Reksa Dana itulah yang disebut dengan Nilai Aktiva Bersih (NAB). Secara singkat, NAB suatu Reksa Dana adalah jumlah total dana kelolaan yang dikelola oleh Manajer Investasi atas produk Reksa Dana yang dimaksud. NAB dihitung dari total harga pasar atas aset (seperti saham, surat utang dan deposito) dalam portofolio suatu Reksa Dana, ditambah dengan biaya pencadangan bunga dari surat utang atau deposito pada portofolio, dikurangi biaya-biaya operasional Reksa Dana seperti biaya pengelolaan, biaya kustodi, pajak dan lainnya. Hasilnya, NAB adalah nilai yang sudah bersih (net) yang tidak lagi terkena pajak.

Banyak juga mengenal yang namanya Nilai Aktiva Bersih per Unit Penyertaan (NAB/UP). Jika NAB merupakan jumlah total dana kelolaan suatu Reksa Dana, NAB/UP adalah harga/nilai setiap satu unit penyertaan Reksa Dana yang dapat dihitung dengan membagi NAB dengan total unit penyertaan yang dimiliki seluruh investor dalam Reksa Dana tersebut. Saat membeli suatu produk Reksa Dana, seorang investor akan disebut sebagai pemegang unit penyertaan. Banyaknya unit penyertaan yang ia miliki tergantung pada NAB/UP Reksa Dananya serta dana investasinya. Sama seperti NAB, NAB/UP juga akan berfluktuasi setiap hari mengikuti harga pasar dari instrumen investasi yang terdapat dalam portofolionya.

Dari hasil klasifikasi Nilai Aktiva Bersih (NAB) yang ada pada lampiran 5 terdapat 10 reksadana yang menjadi sampel awal penelitian yang dilakukan oleh peneliti yaitu sebagai berikut : 
Tabel 2.5 Tabel

Klasifikasi Nilai Aktiva Bersih (NAB)

\begin{tabular}{|l|l|l|c|}
\hline No & \multicolumn{1}{|c|}{ Nama Reksa Dana } & \multicolumn{1}{|c|}{$\begin{array}{c}\text { Total NAB } \\
\mathbf{2 0 1 9}\end{array}$} & $\begin{array}{c}\text { Return Sejak } \\
\text { Peluncuran }\end{array}$ \\
\hline 1 & Simas Syariah Unggulan & $1,115.92$ & $11,59 \%$ \\
\hline 3 & Simas Saham Unggulan & $1,885.90$ & $88,59 \%$ \\
\hline 4 & $\begin{array}{l}\text { Principal Islamic Equity Growth } \\
\text { Syariah }\end{array}$ & $1,459.36$ & $45,94 \%$ \\
\hline 5 & BNM Saham Agresif & 809.79 & $-1902.00 \%$ \\
\hline 6 & Reksa Dana Eastspring Investments & $1.276,23$ & $6263.53 \%$ \\
\hline 7 & BNI-AM Dana Saham Inspiring & $1,128.44$ & $27,62 \%$ \\
\hline 8 & BNP Paribas Pesona & $26,718.44$ & $3,94 \%$ \\
\hline 9 & BNP Paribas Infrastruktur & $3,055.71$ & $16,18 \%$ \\
\hline 10 & First State IndoEquity Dividend Yield & $4,697.93$ & $9,31 \%$ \\
\hline & Fund & & $11,79 \%$ \\
\hline
\end{tabular}

Dari data yang diperoleh peneliti bahwa dapat diberikan penjelasan untuk Nilai Aktiva Bersih (NAB) akan menggambarkan kinerja dari reksa dana itu sendiri, semakin tinggi Nilai Akiva Bersih (NAB) dari produk reksa dana saham akan sejalan terhadap kinerja reksa dana saham itu sendiri, sehingga bisa di tarik penjelasan dari data di atas untuk mengukur kinerja reksa dana saham jika di lihat dari tingkat Nilai Aktiva Bersih (NAB) semakin tinggi tentunya akan memiliki kinerja yang semakin baik sehingga dapat diberikan penjelasan bahwa besaran Nilai Aktiva Bersih (NAB) dapat dijadikan sebagai tolak ukur kinerja dari reksa dana saham di platform PT. Phillip Sekuritas Indonesia.

\section{KESIMPULAN DAN SARAN Kesimpulan}

Penelitian ini bertujuan untuk melihat kinerja reksa dana saham yang terdaftar pada platform PT. Phillip Sekuritas Indonesia Tahun 2019, berdasarkan hasil penelitian dan pembahasan penulis menyimpulkan sebagai berikut : (1). Kinerja reksa dana saham jika dilihat dari total Asset Under Management (AUM) pada platform PT. Phillip Sekuritas Indonesia memiliki kinerja yang baik apabila produk reksa dana saham tersebut memiliki tingkat Asset Under Management (AUM) yang besar karena itu menggambarkan kepercayaan investor terhadap reksa dana saham. (2). Kinerja reksa dana saham jika di lihat dari Stock Selection pada platform PT. Phillip Sekuritas Indonesia memiliki kinerja yang baik apabila pengalokasian besaran persentase investasi dalam satu portofolio reksa dana 


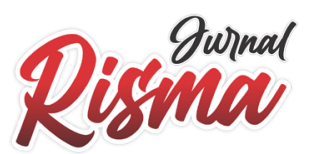

Vol. 1 No. 4 Desember 2021

saham dilakukan dengan tepat pada instrument investasi yang memberikan imbal hasil yang tinggi. (3). Kinerja reksa dana saham jika dilihat dari Fee Broker pada platform PT. Phillip Sekuritas Indonesia memiliki kinerja yang baik apabila besara fee yang dikeluarkan oleh investor semakin kecil akan menarik minat investor untuk melakukan investasi pada reksa dana saham itu sendiri, karena semakin besar fee yang dikeluarkan oleh investor akan berpengaruh terhadap imbal hasil yang akan diterima oleh investor. (4). Kinerja reksa dana saham jika dilihat dari Nilai Aktiva Bersih (NAB) pada platform PT. Phillip Sekuritas Indonesia memiliki kinerja yang baik apabila Nilai Aktiva Bersih (NAB) terus meningkat karena itu menggambarkan imbal hasil yang diterima oleh investor dan ketepatan dari alokasi investasi yang ada pada komposisi reksa dana saham

\section{Implikasi Penelitian}

Adapun implikasi pada penelitian ini dapat dijelaskan berdasarkan hasil penelitian yang terdiri atas implikasi teoritis, praktisn dan kebijakan. (1). Secara teoritis diharapkan dapat memperkaya ilmu pengetahuan pada umumnya dan dapat dijadikan sebagai referensi dalam mata kuliah investasi dan pasar modal serta menjadi sarana penerapan dari teori portofolio . selain itu, hasil penelitian ini dapat dijadikan sebagai acuan untuk peneliti melakukan penelitian berikutnya terkait dengan reksa dana. (2). Secara praktis diharapkan dapat memberikan sumbangsih pemikiran,terhadap keputusan investasi yang dilakukan oleh investor dengan memadukan 4 variabel yang menjadi fokus dalam penelitian ini dan di ikuti dengan informasi-informasi yang menunjang di luar dari penelitian ini. (3). Secara kebijakan diharapkan dapat menjadi bahan pertimbangan untuk investor dan sebagai bahasn evaluasi untuk Manajer Investasi (MI) yang menerbitkan reksa dana saham untuk proaktif dalam penempatan dan pengalokasian asset-asset dalam portofolio reksa dana saham yang diterbitkan.

\section{Saran Penelitian}

Berdasarkan hasil dan kesimpulan penelitian, maka peneliti memberikan saran untuk Penelitian berikutnya dapat mengkolaborasikan dengan menggunakan jenis reksa dana yang lainnya seperti reksa dana pasar uang (Money Market), reksa dana pendapatan tetap (Fix Income), reksa dana campuran (Balance), dan yang terbaru produk dari bursa efek Indonesia yaitu jenis exchange Trade Fund (ETF). Penelitian berikutnya dapat memperkaya data dengan menganalisis bagian propektus dari resa dana itu sendiri, tidak hanya pada satu item yaitu kinerja tahunan dari reksa dana.

Penelitian berikutnya bisa menggunakan analisa yang lebih luas seperti menggunakan SPSS atau LPS dengan jangka waktu yang relatif panjang seperti 5 tahun terakhir. Investor sebaiknya dapat lebih menganalisis informasi seperti Asset Under Management, (AUM), Fee Broker, Stock Selection, dan Nilai Aktiva Bersih (NAB). Hal ini dapat meminimalisir risiko dalam penempatan investasi dari

investor itu sendiri.

\section{REFERENSI}

Abi, F. P. P.(2016). Semakin Dekat dengan Pasar Modal Indonesia. Yogyakarta: Deepublish. Abdallah, Z. (2018). Pengaruh Nilai Tukar Rupiah Terhadap Return Saham Dengan Return On Asset Sebagai Variabel Intervening Pada Perusahaan Rokok. Akuisisi I Jurnal Akuntansi, Vol. 14, No1. 
Afiyati, H. T., \& Topowijono, T.(2018). Pengaruh Inflasi, BI Rate dan Nilai Tukar terhadap Return Saham (Studi Pada Perusahaan Sub Sektor Food \& Beverages yang Terdaftar di Bursa Efek Indonesia Periode 2013-2016). Jurnal Administrasi Bisnis, Vol. 61, No. 2, 144-151.

Amrillah, M. F.(2016). Pengaruh Nilai Tukar Rupiah (Kurs), Inflasi Dan Pertumbuhan Ekonomi Terhadap Return Saham Pada Perusahaan Perbankan yang Terdaftar di Bursa Efek Indonesia (BEI) Periode 2008-2014. Jurnal Valuta, Vol. 2, No. 2, 232250.

Artini, L. G. S.(2018). Variabel-variabel yang Mempengaruhi Return Saham pada Perusahaan Property dan Real Estate di BEI. E-Jurnal Akuntansi dan Bisnis Universitas Udayana, Vol. 7, No.5, 1495-1528.

Bank Indonesia. Laporan Perekonomian Indonesia. https://www.bi.go.id/id/publikasi/laporan- tahunan/perekonomian/Default.aspx Diakses pada tanggal 1 Januari 2020 pukul 12.00 WITA

Bobbi, B., \& Haryanto, A. M.(2017). Analisis Pengaruh Foreign Inflow, Inflasi, Suku Bunga dan Kurs pada Return Saham. Diponegoro Journal of Management, Vol. 6, No. 2, 1 11.

Bursa Efek Indonesia. Pengantar Pasar Modal. https://www.idx.co.id/investor/pengantarpasar-modal/.Diakses pada tanggal 30 November pukul 19.00 WITA

Bustami, F., \& Heikal, J.(2019). Determinants of Return Stock Company Real Estate and Property Located in Indonesia Stock Exchange. International Journal of Economics and Financial Issues, Vol. 9, No. 1, 79-86.

Fahmi, I. (2012). Pengantar Pasar Modal. Alfabeta. Bandung.

Ghozali, I. (2016). Aplikasi Analisis Multivariative dengan Program IBS SPSS 23. Semarang: BPFE Universitas Diponegoro.

Haryani, S. (2018). Pengaruh Inflasi, Nilai Tukar Rupiah/Dolar AS, Tingkat Suku Bunga BI, DER, ROA, CR, dan NPM terhadap Return Saham. Jurnal Nominal, Vol. 7, No. 2, 108-124.

Hartono, Jogiyanto. (2013). Teori Portofolio dan Analisis Investasi. BPFE. Yogyakarta.

Harlina, V. R., \& Khoiruddin, M. (2018). Dividend Policy and Economic Variable to Stock Price Votability: Comparison of Indonesia and Malaysia. Management Analysis Journal, Vol. 7, No. 4, 507-515.

Indraswari, A. A. R., \& Suryantini, N. P. S.(2013). Pengaruh Kondisi Ekonomi, Kondisi Pasar Modal, dan Kinerja Keuangan terhadap Return Saham pada Perusahaan Automotive and Allied Products di BEI. E-Jurnal Manajemen Unud, Vol. 2, No. 12, 1597-1616.

Juliana, S. F., Pahlevi, C., \& Amas, Y. (2019). Faktor-faktor yang Mempengaruhi Return Saham Perusahaan Perbankan yang Terdaftar di BEI Periode 2012-2017. Jurnal Bisnis, Manajemen dan Informatika, Vol. 15, No. 2, 305-321.

Maharditya, M. A., Layyinaturrobaniyah, L., \& Anwar, M. (2018). Implication of Macroeconomic Factors to Stock Return of Indonesian Property and Real Estate Companies. Jurnal Dinamika Manajemen, Vol. 9, No. 1, 100-113. 


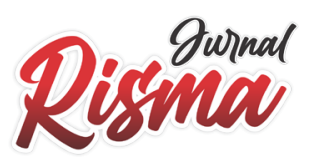

Vol. 1 No. 4 Desember 2021

Mie, M.(2014). Analisis Pengaruh Indeks Harga Saham Gabungan Asing Terhadap Indeks Harga Saham Gabungan Indonesia. Jurnal Wira Ekonomi Mikroskil, Vol. 4, No. 2, 81-90.

Miller, M. H., \& Modigliani, F. (1961). Dividend Policy, Growth and the Valuation of Shares. The Journal of Business, Vol. 34, No. 4, 411-433.

Mirayanti, N. M., \& Wirama, D. G.(2017). Pengaruh Variabel Ekonomi Makro Pada Return Saham LQ45 di Bursa Efek Indonesia. E-Jurnal Akuntansi Universitas Udayana, Vol. 21, No. 1, 505-533.

Nopirin. (2009). Ekonomi Moneter. Edisi Satu. Cetakan ke 12. Jakarta: BPPE.

Nurhidayat, R. (2009). Pengaruh Variabel Ekonomi Makro Terhadap Return Saham Properti Pada Bursa Efek Indonesia. Kajian Ekonomi dan Keuangan, Vol. 13, No. 2, $1-14$.

Parwati, R. A. D., \& Sudiartha, G. M. (2016). Pengaruh profitabilitas, leverage, likuiditas dan penilaian pasar tehadap return saham perusahaan manufaktur. E-Jurnal Manajemen Universitas Udayana, 5(1).

Pradnya, I. M. P. D. P., \& Purbawangsa, I. B. A. (2017). Pengaruh Rasio Keuangan, Kondisi Pasar Modal, dan Perubahan Nilai Tukar terhadap Return Saham. E-Jurnal Manajemen Unud, Vol. 6, No. 2, 663-696.

Pujawati, P. E., Wiksuana, I. G. B., \& Artini, L. G. S.(2015). Pengaruh Nilai Tukar Rupiah terhadap Return Saham dengan Profitabilitas sebagai Variabel Intervening. E-Jurnal Ekonomi dan Bisnis Universitas Udayana, Vol. 4, No. 4, 220-242.

Riduwan, R., \& Adun, E.(2013). Cara Mudah Belajar SPSS Versi 17.0 dan Aplikasi Statistik Penelitian. Bandung: Alfabeta.

Sartika, D., \& Salim, M. A.(2018). Jurnal Ilmiah Riset Manajemen, Vol. 7, No.9, 23-37.

Silim, L. (2013). Pengaruh Variabel Ekonomi Makro terhadap Indeks Harga Saham Gabungan pada Bursa Efek Indonesia Periode 2002-2011. Jurnal Ilmiah Mahasiswa Universitas Surabaya, Vol. 2, No. 2, 1-18.

Silvatika, B. A., \& Widiyanti, M. (2018). Financial Analisis Pengaruh Faktor Fundamental dan Teknikal Terhadap Return Saham. Jurnal Dinamika Manajemen Dan Bisnis, $1(2)$.

Simorangkir, I., \& Suseno. (2004). Sistem dan Kebijakan Nilai Tukar, Seri Kebanksentralan No. 12. Pusat Pendidikan dan Studi Kebanksentralan Bank Indonesia (PSSK BI) : Jakarta.

Spence, M. (1973). Job market signaling.Quarterly Journal of Economics, Vol. 87, No. 3, pp: 355-374. Suciwati, D. P. (2002). Pengaruh Risiko Nilai Tukar Rupiah Terhadap Return Saham Studi Empiris Pada Perusahaan Manufaktur yang Terdaftar di BEJ. Jurnal Ekonomi dan Bisnis, Vol. 17, No.4, 347-360.

Sugiyono. (2016). Metodologi Penelitian Kuantitatif, Kualitatif, dan R\&D. Bandung: CV Alfabeta.

Sunariyah. (2003). Pengetahuan Pasar Modal. Edisi Ketiga. Yogyakarta. Unit Penerbit dan Percetakan (UPP) AMP YKPN.

Tandelilin, E. (2010). Portofolio dan Investasi Teori dan Aplikasi. Yogyakarta: Kanisius.

Triyono, T. (2008). Analisis Perubahan Kurs Rupiah Terhadap Dolar Amerika. Jurnal Ekonomi Pembangunan, Vol. 9, No.2, 156-167. 
Widodo, W. (2018). Analisis Pengaruh Indeks Harga Saham Gabungan Regional Asia terhadap Indeks Harga Saham Gabungan Indonesia. Jurnal Ekonomi dan Bisnis, Vol. 1, No.2, 148-164.

Yuswandy, Y. (2012). Analisis Pengaruh Harga Minyak Dunia, Harga Emas Dunia, Nilai Tukar Rupiah, dan Indeks IHSG terhadap Return Saham (Studi Kasus Saham-Saham Sinarmas Group). Jurnal Pasar Modal dan Perbankan, Vol. 1, No. 1, 39-61.

Zulfikar. (2016). Pengantar Pasar Modal dengan Pendekatan Statistik. Yogyakarta: Deepublish. 